\title{
Characterization and pathogenicity on seedlings of Pythium species isolated from soybean roots in the Toulouse area
}

\author{
GA Forbes *, P Davet ** \\ INRA, Laboratoire de Pathologie Végétale de I'ENSA, 34060 Montpellier, France
}

(Received 23 July 1990; accepted 9 October 1990)

\begin{abstract}
Summary - Isolation frequencies and in vitro pathogenicity are given for several species of Pythium isolated from roots of soybean plants growing near Toulouse (SW France). Approximately half of all isolates were pathogenic on soybean seedlings (cv Kingsoy) at $20^{\circ} \mathrm{C}$. Some differences among isolates could be detected, but the variability among species was greater in the isolates studied. The most pathogenic species was $P$ ultimum which reduced root elongation to approximately $6 \%$ of the control but made up only $10 \%$ of the total isolates in 2 years of sampling, slightly varying from one year to the next. $P$ sylvaticum and $P$ irregulare were isolated more frequently $(26$ and $13 \%$, respectively) and were pathogenic on soybean, reducing root elongation by 30 to $50 \%$ of the control in 2 tests. The most commonly isolated group (38\%) did not form oospores and was classified as HS (hyphal swelling). This group appeared to have little effect on soybean root growth and caused no visible symptoms. $P$ ultimum was only isolated from young plants; $P$ irregulare was isolated primarily during the first two months of growth; and $P$ sylvaticum and the HS group were isolated in a fairly uniform manner throughout the first 3 months of the season.
\end{abstract}

Pythium ultimum / Pythium sylvaticum / Pythium irregulare / soybean / Glycine max

Résumé - Caractérisation et pouvoir pathogène sur plantules de Pythium spp isolés de racines de soja dans la région de Toulouse. Plusieurs espèces de Pythium ont été isolées de racines de soja en 1986 et 1987 dans la région de Toulouse, à 3 stades de développement des plantes. Environ la moitié de l'ensemble des isolats se révèle pathogène sur des germinations de la variété Kingsoy maintenues à $20^{\circ} \mathrm{C}$ (tableau I). La variabilité du pouvoir pathogène à l'intérieur d'une même espèce de Pythium est faible, alors qu'il existe des différences importantes entre les espèces dans les échantillons observés (tableau II). L'espèce la plus agressive est $\mathrm{P}$ ultimum qui réduit l'allongement des racines à près de $6 \%$ de celui des témoins. Elle ne représente cependant que $10 \%$ du total des isolements des 2 années, avec une légère variation d'une année à l'autre (fig 1). La fréquence d'isolement de $\mathrm{P}$ sylvaticum et de $\mathrm{P}$ irregulare est plus élevée (26 et 13\%, respectivement, du total des isolements). Ces 2 espèces ont un pouvoir pathogène important, réduisant l'allongement des racines à 30 à $50 \%$ de celui des témoins. Le groupe le plus fréquent (38\% des isolements), dénommé HS (hyphal swelling) ne forme pas d'oospores. II n'a pas d'effet apparent sur le développement des racines. $\mathrm{P}$ ultimum est isolé seulement sur les plantes jeunes, $\mathrm{P}$ irregulare est isolé au cours des 2 premiers mois; on trouve P sylvaticum et le groupe HS au moins pendant les 3 premiers mois de culture (fig 2).

Pythium ultimum / Pythium sylvaticum / Pythium irregulare / soja / Glycine max

\footnotetext{
* Present address: International Potato Center (CIP), PO Box 5969, Lima, Peru.

** Correspondence and reprints.
} 


\section{INTRODUCTION}

Several species of Pythium have been established as pathogens of soybean seeds and seedlings, and have been shown to cause major damage periodically (Anonymous, 1975). The species considered to be most important are $P$ aphanidermatum, $P$ irregulare, $P$ ultimum and $P$ myryotylum. $P$ debaryanum has also been frequently associated, but the legitimacy of this species has been questioned: the correct denomination probably ought to have been $P$ sylvaticum in most cases (Van der Plaats-Niterink, 1981).

In a related study (Forbes and Davet, 1990) we found that Pythium spp were isolated in the growing season from approximately $20 \%$ of root pieces sampled in the region of SW France near the city of Toulouse. An earlier survey indicated that roots from plants growing in this region were often more discoloured and/or had a greater number of lesions than in other parts of France (Davet and Forbes, 1988). Several key questions arose: 1), what species of Pythium are present in the region; 2), do relative abundances of species change through the season; and 3), what proportion of isolates are pathogenic on soybean. The following study was designed to address these questions. In this work, pathogenicity tests were limited to seedlings.

\section{MATERIALS AND METHODS}

Pythium isolates used in this study were collected during the 1986 and 1987 growing seasons. In 1986, isolations were made from randomly sampled plants (cultivars Kingsoy and Kador) originating from 12 fields in an area of approximately $400 \mathrm{sq} \mathrm{km}$ delimited by the towns of Toulouse, Buzet sur Tarn, Lavaur, and Caraman. This region is representative of one of the most important areas of soybean production in France. Twenty-four isolates were kept for characterization and 20 of these were compared for pathogenicity.

In 1987 and as part of a larger study, 10 fields (cv Kador) were periodically sampled in the same region. Sampling and isolation procedures have been described (Forbes and Davet, 1990). Cultures of Pythium were kept from 3 of the sampling dates: 28,49 and $\mathbf{8 5} \mathrm{d}$ after planting, chosen to represent the early, middle and late growing season. The isolation procedures described by Forbes and Davet (1990) were also used for isolates taken in 1986.

Pythium spp were maintained on potato carrot agar (PCA) (Van der Plaats-Niterink, 1981) or half-strength commercial corn meal agar (CMA). Species were identified according to the key of Van der PlaatsNiterink (1981).
Isolates were tested in the laboratory for pathogenicity in a paper blotter apparatus as described by Singleton and Ziv (1981). Surface-disinfected soybean seeds (cv Kingsoy) were pre-germinated at $24^{\circ} \mathrm{C}$ for $48 \mathrm{~h}$. Two seedlings, selected for lack of contamination and uniformity of root growth, were placed in a blotter (10 cm wide by $15 \mathrm{~cm}$ long) which was suspended in a plastic tray such that the bottom of the blotter was continuously in water. Lighting was provided by fluorescent tubes at a distance of about $30 \mathrm{~cm}$ from the top of the blotter, adjusted to a 14-h photoperiod. After $24 \mathrm{~h}$ in the blotters at $20^{\circ} \mathrm{C}$, the seedlings were inoculated by placing a $0.5-\mathrm{cm}$ agar disk (CMA) of a 1-wk culture adjacent to the root tip. At the time of inoculation root length varied between 3 and $5 \mathrm{~cm}$.

Blotters, each constituting one experimental unit, were randomly arranged in the trays, 15 blotters per tray. It was assumed that there was no effect of tray, and data were analyzed according to a completely randomized design.

Twenty of the 1986 isolates were compared in an experiment with 3 replications. The effects of inoculation were measured on hypocotyl length and root elongation beyond the point of inoculation. To aid interpretation, root elongation was converted to a percentage loss of the control in the following manner: $Y=(A / B) x$ 100 ; where $Y=$ the percentage value, $A$ is the measured length of an inoculated root, and $B$ is the average length of the replicated, noninoculated roots.

In a second experiment, 53 isolates from 1987 were tested with 2 replications. Root elongation and a measure of severity were used to assess isolates in this second experiment. The measure of severity was a scale based on the percentage of the root system affected where $0=$ no lesion, $1=$ a small lesion covering up to $10 \%$ of the root system, $2=$ lesion spreading to $50 \%$ of the root system, and $3=$ more than $50 \%$ of the root system affected.

\section{RESULTS}

\section{Isolation frequencies (IF's)}

The isolates from 1986 and 1987 primarily comprised 3 species and the HS group which formed no oospores. This group was the most common type isolated making up approximately $38 \%$ of the 78 isolates characterized (table I).

$P$ sylvaticum followed the HS group representing $25.6 \%$ of the isolates. $P$ irregulare and $P$ ultimum followed with 12.8 and $10.3 \%$ respectively. These 3 species plus HS made up $87 \%$ of all isolates. Three $P$ echinulatum and one each of $P$ aphanidermatum and $P$ violae were also isolated. Five isolates were not identified to species.

The general spectrum of species was the same for the $2 \mathrm{yr}$, with $P$ sylvaticum (both mating 
Table I. Pathogenicity and frequencies of Pythium spp isolated from soybean roots in the Toulouse area.

\begin{tabular}{|c|c|c|c|c|c|c|c|}
\hline \multirow[t]{2}{*}{ Species } & \multirow{2}{*}{\multicolumn{2}{|c|}{$\begin{array}{c}\text { Isolation } \\
\text { number (frequency) }{ }^{1}\end{array}$}} & \multirow{2}{*}{\multicolumn{2}{|c|}{$\begin{array}{l}1986 \\
R E^{2}\end{array}$}} & \multicolumn{3}{|c|}{1987} \\
\hline & & & & & \multicolumn{2}{|c|}{$R E$} & SEV 3 \\
\hline 'HS' & 30 & $(0.38)$ & 83.4 & 13 & 88.5 & 123 & 0.30 \\
\hline$P$ sylvaticum & 20 & $(0.26)$ & 30.3 & 18 & 39.4 & $/ 12$ & 2.45 \\
\hline$P$ irregulare & 10 & $(0.13)$ & 5.0 & $/ 1$ & 46.1 & 18 & 2.60 \\
\hline$P$ ultimum & 8 & $(0.10)$ & 5.0 & 16 & 6.5 & 12 & 2.84 \\
\hline$P$ echinulatum & 3 & $(0.04)$ & & 10 & 87.5 & $/ 3$ & 0.67 \\
\hline$P$ aphanidermatum & 1 & $(0.01)$ & 80.0 & $/ 1$ & & 10 & 1.00 \\
\hline$P$ violae & 1 & $(0.01)$ & & 10 & 64.2 & 11 & 2.00 \\
\hline Pythium spp & 5 & $(0.06)$ & 80.1 & $/ 1$ & 92.9 & 14 & 0.00 \\
\hline Total & 78 & & & 120 & & $/ 53$ & \\
\hline $\mathrm{LSD}^{4}$ & & & 51.6 & & 23.5 & & \\
\hline
\end{tabular}

\footnotetext{
1 Numbers in parentheses indicate the proportion of the total 78 that were isolated in 1986 and 1987.

2 Percentage root elongation relative to the control. The number following the slash represents the number of isolates tested.

3 Severity based on percentage of root system affected where $0=$ no lesion, $1=$ a small contained lesions at the point of inoculum, 2 = lesion spreading to $50 \%$ of the root system, and $3=$ lesion covering more than $50 \%$ of the root system

4 Least significant difference.
}

types considered together) and HS having the greatest IF's (fig 1). $P$ ultimum and $P$ irregulare were predominantly isolated in the early part of the season (fig 2). In contrast, isolation date had little effect on $P$ sylvaticum and HS.

\section{Species characterization}

Among the isolates classified as HS there were 2 types that differed for several characteristics. Isolates of the dominant type (24 of 30 isolates) on PCA were submerged with a very distinct "carnation" (Van der Plaats-Niterink, 1981) pattern. Hy-



Fig 1. Isolation frequencies for selected Pythium spp isolated from soybean roots in 1986 and 1987. Code: Syl(M) and Syl $(F)=P$ sylvaticum male and female, respectively; $I R R=P$ ir regulare; ULT $=P$ ultimum; 'HS' = hyphal swelling group. phal width reached approximately 5-7 $\mu \mathrm{m}$ and colony growth was $14-15 \mathrm{~mm}$ per day at $24^{\circ} \mathrm{C}$. Hyphal swellings were abundant and averaged $20 \mu \mathrm{m}$ in diameter. There was no aerial growth on CMA. Isolates of the second HS type were not homogeneous for aerial growth on CMA or growth pattern on PCA, but were all (6 isolates) characterized by a slow growth rate $(5-7 \mathrm{~mm}$ per day at $24^{\circ} \mathrm{C}$ ).

On PCA, $P$ irregulare appeared generally as described by Van der Plaats-Niterink (1981). One exception, which has been reported in another study (Chamswarng and Cook, 1985), was that most isolates produced small limaform hy-

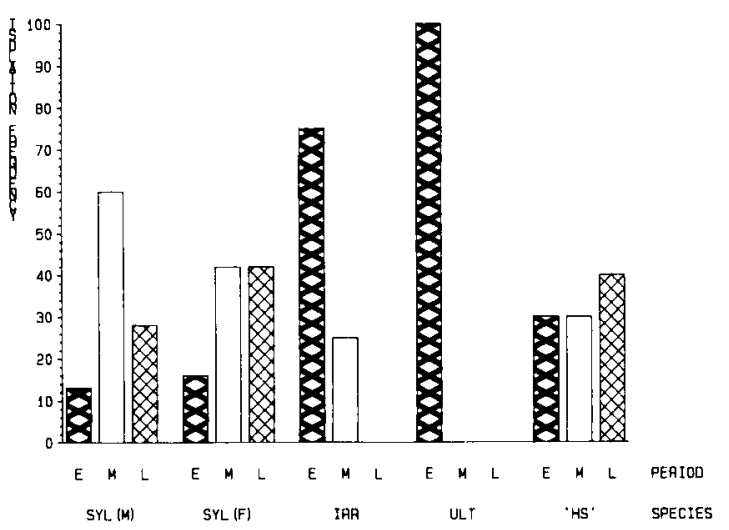

Fig 2. Isolation frequencies for selected Pythium spp at 3 isolation times in 1987. Code: early $(E)$, mid $(M)$ and late $(L)$ $=28,49$, and $85 \mathrm{~d}$ after planting, respectively; Syl(M) and Syl(F) = $P$ sylvaticum male and female, respectively; IRR = $P$ irregulare; ULT $=P$ ultimum, HS $=$ hyphal swelling group. 
phal swellings and only rarely produced large globose hyphal swellings. Young antheridia were often highly falcate in water culture, but appeared to swell with maturation, suggesting that this characteristic is less useful in diagnosis than has been proposed (Vaartaja, 1967).

$P$ ultimum isolates did not produce sporangia or zoospores and therefore belong to the variety ultimum. Colonies produced abundant cottony aerial growth on CMA but no discernible growth pattern on PCA or CMA.

Cultures of $P$ sylvaticum were similar to $P$ ultimum on CMA and PCA. All isolates except one produced oospores when crossed with known mating types. In 1986, isolates were primarily of the male mating type, but in 1987 both mating types were isolated with similar frequency (fig 1).

\section{Pathogenicity}

In the first experiment involving the 1986 isolates a significant difference could be established among isolates for root elongation (table II). Based on the level of significance and R-square values, hypocotyl length did not appear to be a good indicator of differences among fungal isolates: the problems associated with the measure of hypocotyl length in our pathogenicity tests are probably due to the nature of the apparatus. The uniform humidity of the blotter supplies sufficient moisture to the functional part of the root above the point of inoculation.

Overall, the analysis of variance showed that the majority of variability occurred among species rather than among isolates of a given species. For this reason we have reported levels of root elongation and severity for species means (table 1). $P$ ultimum, $P$ sylvaticum and $P$ irregulare significantly reduced root elongation and caused severe root necrosis. Reduction in root elongation was generally consistent for both tests and $P$ ultimum had a greater effect than the other 2 pathogenic species. The only other species which was clearly pathogenic in this study was $P$ violae, but it was only represented by one isolate. The other species and HS group appeared to have little or no effect on root growth.

\section{DISCUSSION}

In a related study, we found that approximately $20 \%$ of all root pieces sampled in the study re- gion were infected with Pythium spp in a year that was not favourable for seedling disease (Forbes and Davet, 1990). IF's of Pythium spp decreased with time, and were more uniform in 10 fields sampled than were IF's for most of the other fungal species studied. Since about half of the Pythium isolates we characterized were pathogenic, we estimate that approximately $10 \%$ of all root pieces sampled on 3 different sampling dates contained pathogenic isolates. This estimate can be seen as quantitative though indirect, evidence for the common assumption that $\mathrm{Py}$ thium spp are ubiquitous organisms that cause periodic damage when environmental conditions are favourable (Hendrix and Campbell, 1973).

In both 1986 and 1987 we noticed a high degree of homogenicity for pathogenicity within species. Some differences among isolates could be detected, but the variability among species was much greater (table II). This homogenicity could result from the fact that all the isolates come from only 1 or 2 cultivars of the same host and a limited geographical region. If comparative studies from other geographical regions were to support this finding, it would mean that simple taxonomic determination of Pythium spp on soybean would furnish important information concerning the pathogenicity of the Pythium population being sampled.

The most pathogenic species (under the conditions of our test) was $P$ ultimum, which was isolated at a relatively low frequency $(10.3 \%)$. All $P$ ultimum isolates, however, were obtained during the early part of the season, when plants are more susceptible. The greater importance of $P$ ultimum in 1986 probably reflects the wet and cool conditions which prevailed after planting. In the last 10 days of April, $24 \mathrm{~mm}$ of rain fell and soil temperature at a depth of $10 \mathrm{~cm}$ was less than $15^{\circ} \mathrm{C}$. In the same post-planting period in 1987 , only $0.9 \mathrm{~mm}$ of rain fell and soil temperature was consistently above $15^{\circ} \mathrm{C}$. If conditions in 1987 had been conducive to this species, which is more pathogenic in cool, wet soils (Lumsden et al, 1976), IF's would probably have been higher.

Nonetheless, there is reason to suspect that the importance of $P$ ultimum has been exaggerated in the past. It is one of the most common soilborne Pythium spp (Van der Plaats-Niterink, 1981) and recent soil isolation studies do show that high levels of $P$ ultimum occur in northern European soils (Messiaen et al, 1977; Bottcher and Behr, 1985). However, it may not be valid to assume epidemiological significance for all crops 
Table II. Analysis of variance for two experiments testing pathogenicity of Pythium isolates on hypocotyl length and/ or root elongation of soybean seedlings. Root elongation is measured beyond the point of inoculation.

\begin{tabular}{|c|c|c|c|c|}
\hline Independant variable & $D F$ & $\begin{array}{c}\text { Mean } \\
\text { squares }\end{array}$ & $\begin{array}{c}\text { Level of } \\
\text { significance }\end{array}$ & $R$-square \\
\hline \multicolumn{5}{|l|}{$\begin{array}{l}\text { Hypocotyl length } \\
(1986)\end{array}$} \\
\hline $\begin{array}{c}\text { Model }^{1} \\
\text { Species } \\
\text { Isolate (Species) } \\
\text { Error }\end{array}$ & $\begin{array}{r}19 \\
6 \\
13 \\
40\end{array}$ & $\begin{array}{l}288.38 \\
407.08 \\
233.59 \\
170.71\end{array}$ & $\begin{array}{l}0.0807 \\
0.0460 \\
0.2172\end{array}$ & 0.4452 \\
\hline \multicolumn{5}{|l|}{$\begin{array}{l}\text { Root elongation } \\
\text { (1986) }\end{array}$} \\
\hline $\begin{array}{c}\text { Model } \\
\text { Species } \\
\text { Isolate (Species) } \\
\text { Error }\end{array}$ & $\begin{array}{r}19 \\
6 \\
13 \\
40\end{array}$ & $\begin{array}{r}3570.18 \\
10279.95 \\
473.36 \\
226.39\end{array}$ & $\begin{array}{l}0.0001 \\
0.0001 \\
0.0372\end{array}$ & 0.8822 \\
\hline \multicolumn{5}{|l|}{ (1987) } \\
\hline $\begin{array}{c}\text { Model } \\
\text { Species } \\
\text { Isolate (Species) } \\
\text { Error }\end{array}$ & $\begin{array}{r}52 \\
6 \\
46 \\
51\end{array}$ & $\begin{array}{r}1498.16 \\
11400.02 \\
206.61 \\
135.62\end{array}$ & $\begin{array}{l}0.0001 \\
0.0001 \\
0.0720\end{array}$ & 0.9184 \\
\hline
\end{tabular}

1 Model was: $y=a+b(a)+e$, where $y=$ dependent variable, $a=$ species, $b=$ isolate nested in species, $\theta=$ random error.

based on inoculum density alone. In another quantitative study of root infection of a leguminous plant, $P$ ultimum was only isolated from $1 \%$ of root segments that had been plated (Hall, 1983).

Conditions at the time of sampling the root system appear to greatly influence the probability of finding $P$ ultimum. Our studies indicate, and others (Schlub and Lockwood, 1981) directly demonstrate that $P$ ultimum infection only occurs in a narrow range of soil temperatures and soil moisture levels. This does not negate the potential for severe attack by $P$ ultimum when these conditions exist. In fact, they are frequently met with at emergence time.

Other pathogenic species of Pythium appear to be more common under a wider range of environmental conditions. $P$ sylvaticum and $P$ irregulare represented approximately $40.0 \%$ of our isolates and were isolated on all 3 dates.

The most frequently isolated pathogenic species, $P$ sylvaticum, was not mentioned in at least one review of soybean diseases (Anonymous, 1975). The lack of importance given to $P$ sylvaticum in earlier studies may be due to the difficulty of identifying this species without known mating types. Without mating types, $P$ sylvaticum could easily be placed in the HS group, resulting in an unfortunate taxonomic mixture of pathogenic and nonpathogenic species. We found that isolates of the HS group did not cause the typical symptoms of root decay usually associated with Pythium spp and had little or no effect on root growth. Furthermore, the greatest number of HS isolates were obtained from the last sampling date (fig 2), possibly indicating saprophytic activity.

Overall, these findings confirm the high incidence of pathogenic Pythium spp in the Toulouse area. A further field survey in another part of SW France (Landes and Adour valley) revealed that the same species occurred, with a rather similar distribution. Field observations and greenhouse tests (unpublished results) showed that pathogenic Pythium spp could cause appreciable damping-off under favourable conditions. On the other hand, we lack precise data concerning the practical effects of pathogenic Pythium spp on developed plants.

Our results indicate the need for some investigation into possible varietal differences for resistance. Very few data are available on this subject. Seed treatment with appropriate fungicides could lead to shorter-term results. 


\section{ACKNOWLEDGMENTS}

Major support for the senior author was given by the Chateaubriand grant for post-graduate studies. Significant financial and physical support was also provided by CETIOM (Centre Technique Interprofessionnel des Oléagineux Métropolitains). $P$ sylvaticum mating types were provided by J Mugnier, Rhône Poulenc Agrochimie, Lyon, France.

\section{REFERENCES}

Anonymous (1975) Compendium of Soybean Diseases (Sinclair, JB; Shurtleff MC eds) Am Phytopathol Soc St Paul, MN 55121

Bottcher I, Behr L (1985) Untersuchungen zum Vorkommen von Pythium spp im Boden. I. Die Isolation von Pythiumarten, ihre Differenzierung nach Makroskoscopischen Merkmalen und ihre Bestimmung. Phytopathol Z 112, 333-343

Chamswarng C, Cook RJ (1985) Identification and comparative pathogenicity of Pythium species from wheat roots and wheat-field soils in the Pacific Northwest. Phytopathology 75, 821-827

Davet P, Forbes GA (1988) Les champignons du sol parasites du soja en France. $2^{\theta}$ Conf Intern Maladies des Plantes. Bordeaux, 8-10 November, 1988, 891-896
Forbes GA, Davet P (1990) Association of soybean root mycoflora with root nodulation, root necrosis and plant fresh weight. Ann Appl Biol (in press)

Hall R (1983) Pythium root rot of white bean in Ontario. Can J Plant Pathol 5, 239-244

Hendrix FF, Campbell WA (1973) Pythium as plant pathogens. Annu Rev Phytopathol 11, 77-78

Lumsden RD, Ayers WA, Adams PB, Dow RL, Lewis JA, Papavizas GC, Kantzes JG (1976) Ecology and epidemiology of Pythium species in field soil. Phytopathology 66, 1203-1209

Messiaen CM, Barrière Y, Belliard-Alonzo L, De la Tullaye B, Bouhot D (1977) Étude qualitative des Pythium dans quelques sols des environs de Versailles. Ann Phytopathol 9, 445-465

Schlub RL, Lockwood JL (1981) Etiology and epidemiology of seedling rot of soybean by Pythium ultimum. Phytopathology 71, 134-138

Singleton LL, Ziv O (1981) Effects of Pythium arrhenomanes infection and root tip amputation on wheat seedling development. Phytopathology 71, 316-319

Vaartaja $O$ (1967) Occurrence of falcate antheridia in Pythium species, particularly in $P$ irregulare and its synonym $P$ polymorphon. Mycologia 59, 870-877

Van der Plaats-Niterink AJ (1981) Monograph of the genus Pythium. Centraalbureau voor Schimmelcultures, Baarn. Stud Mycol No 21 